\title{
MORTALITY, PRODUCTION AND QUALITY OF EGGS OF DIFFERENT REARING SYSTEMS
}

\author{
Bartira de O. Tavares ${ }^{1}$, Danilo F. Pereira ${ }^{2 *}$, Douglas D'Alessandro Salgado1, \\ Priscilla A. Bustos Mac-Lean ${ }^{1}$
}

\begin{abstract}
${ }^{2 *}$ Corresponding author. São Paulo State University (UNESP), School of Sciences and Engineering/ Tupã - SP, Brasil. E-mail: danilo@tupa.unesp.br
\end{abstract}

\section{KEYWORDS}

poultry egg farming, alternative egg production, quality of eggs, animal welfare.

\begin{abstract}
The conventional production of eggs in cage systems is intense and compromises the laying hens welfare. More demanding consumer markets have been pushing to abolish the use of cages and thus provide better welfare in poultry laying. This research evaluated the mortality, production, and egg quality of two alternative production systems (free-range and organic free range free-range) and compared them with the conventional system. The research was carried out in two commercial poultry farms and the variables egg weight, shell egg resistance, Haugh unit, mortality and production were recorded during eight months. The results showed that the conventional system presented better production, lower mortality and better shell egg quality. The alternative systems had better internal egg quality. Alternative systems had greater variability in outcomes and problems with disease control, which indicate greater difficulty for proper management.
\end{abstract}

\section{INTRODUCTION}

The need to achieve better levels of productivity and the increasing demand for food resulted in productive systems with high density of animals that cause problems related to animal health and well-being (Moura et al., 2006).

The questions about birds' welfare in productive systems with cages are frequent and alternative productive systems, the cages have been adopted in some properties in order to meet more demanding market niches (Tonsor \& Wolf, 2011).

Variables such as birds' age, ambience and nutrition affect the quality of eggs (Jones et al, 2012; Steenfeldt \& Hammershoj, 2015), however the assessment of the effects and alternative housing systems on egg quality is still not conclusive. These variables can affect the egg and disaggregate economic and qualitative value, bringing losses to the producers (Alleoni \& Antunes, 2001).

Considering the hypothesis that alternative systems without egg production cages provide better welfare conditions for birds and that this gain in welfare should be observed in zootechnical performance, the objective of this study was to compare mortality, production and the quality of eggs produced in conventional system of cages with eggs produced in two alternative systems: organic free range and free-range.

\section{MATERIAL AND METHODS}

The research was carried out in two posture farms located in the region of Tupã-SP, during the period from August 2015 to April 2016. The first one, denominated alternative farm, presented two systems of creation: organic free range and free-range. At the time of the research, there were 49,000 birds in production, a lot of 7,500 birds created in the organic free range system and seven lots, totaling 41,500 birds, raised in the free-range system. The second farm, denominated conventional, located in the city of Bastos-SP and distant $22 \mathrm{~km}$ of the alternative farm. On this farm, there were 48 aviaries and about 120,000 birds in production.

According to the Köppen classification, the two cities have the same climate and season characteristics, classified as Aw and characterized by a tropical climate, with a well defined dry season in the winter period and average annual temperatures higher than $22^{\circ} \mathrm{C}$.

The data records were carried out between August 2015 and December 2015 for eggs from the organic free range system, from August 2015 to March 2016, for eggs from the free-range system and from August 2015 to April 2016 for eggs from the conventional system. It was initially intended to record the data for 12 months, however the time of birds discarding was different in each system, resulting in different data records for each production system. For the comparisons inherent to the quality and production of eggs, we selected sheds in which there were birds of the same lineage and close ages.

\footnotetext{
${ }^{1}$ Universidade Estadual Paulista/ Tupã - SP, Brasil.

Received in: 3-22-2017

Accepted in: 6-12-2018
} 
TABLE 1. Description of the free-range, organic free range and conventional production systems.

\begin{tabular}{|c|c|c|c|}
\hline Description & Free range & Organic & Conventional \\
\hline Dimensions of the shed & $10 \times 100 \mathrm{~m}$ & $10 \times 100 \mathrm{~m}$ & $3 \times 100 \mathrm{~m}$ \\
\hline Roof & Asbestos cement without paint & Asbestos cement without paint & Ceramic roof tile \\
\hline Orientation & East West & East West & North South \\
\hline Structure & Metallic & Metallic & $\begin{array}{l}\text { reinforced concrete } \\
\text { masonry walls }\end{array}$ \\
\hline Floor & Concrete & Concrete & Concrete \\
\hline Cages & Do not have & Do not have & $\begin{array}{l}\text { Birds housed in pairs } \\
(0.45 \times 0.45 \times 0.25 \mathrm{~cm})\end{array}$ \\
\hline Batteries & Do not have & Do not have & 4 batteries of 2 floors \\
\hline Beds & $\begin{array}{l}\text { Maravalha } 5 \mathrm{~cm} \\
\text { (Pinus) }\end{array}$ & $\begin{array}{l}\text { Maravalha } 5 \mathrm{~cm} \\
\text { (Pinus) }\end{array}$ & Do not have \\
\hline Perch & 10 meters $(600$ birds per meter & $\begin{array}{l}13.5 \text { meters ( } 555 \text { birds per } \\
\text { meter) }\end{array}$ & Do not have \\
\hline Nest & 300 nests - 20 birds per nest & 380 nets -19.7 birds per nest & Do not have \\
\hline Lighting & Mixed (15 hours) & Mixed (15 hours) & Artificial (16.5 hours) \\
\hline Pasture Area & 2.000 meters & 2.000 meters & Do not have \\
\hline Grazing Time & $\begin{array}{l}3 \text { to } 4 \text { hours per day } \\
\text { (Brachiária decumbens) }\end{array}$ & $\begin{array}{l}3 \text { to } 4 \text { hours per day (Brachiária } \\
\text { decumbens) }\end{array}$ & Do not have \\
\hline Feeding & Feed produced on the farm & $\begin{array}{l}\text { Organic Feed produced on the } \\
\text { farm }\end{array}$ & Feed produced on the farm \\
\hline Water & commuting drinkers & commuting drinkers & Nipple drinkers \\
\hline Number of initial birds & 6.000 & 7.500 & 20.000 \\
\hline Lineage & Hy-line Brow & Hy-line Brow & Hy-line Brow \\
\hline Age of birds & 43 weeks & 50 weeks & 41 weeks \\
\hline Egg Collection & Manual twice a day & Manual once a day & Manual once a day \\
\hline Cleaning of the sheds & In batch exchange & In batch exchange & Frequently \\
\hline
\end{tabular}

Every 30 days, 60 eggs from each shed representing the breeding system were randomly collected. From the collected eggs, we recorded the variables: egg weight, bark resistance and Haugh unit. These analyzes were performed at the Bastos Poultry Pathology Laboratory, using the model machine DET6000 (NABEL Co. Ltd. Kyoto, Japan).

Mortality and egg production were recorded by the producer and the monthly total of these two variables, for the sheds that were being evaluated, were available for analysis. To investigate possible causes of high mortality, unstructured interviews with the producers were conducted.

Due to the age of the birds were not the same and to interfere in the analyzed variables (Barbosa et al., 2012), the analyzes were performed by means of interval charts with confidence of $95 \%$ for the observed averages of the variables egg weight, bark resistance, Haugh Unit, mortality and yield for each of the systems studied, comparing with that expected for the lineage at that age described in the lineage manual. For better visualization, these data were normalized so that the variation observed in the experimental data became more evident.

\section{RESULTS AND DISCUSSION}

The variation of the mean egg weight compared to that expected is shown in Figure 1. The desired data for the egg weight characteristic are presented by a range delimited by dashed lines, with the upper and lower lines showing the limits of those weight ranges of the expected egg and the center line indicates the expected average value. 


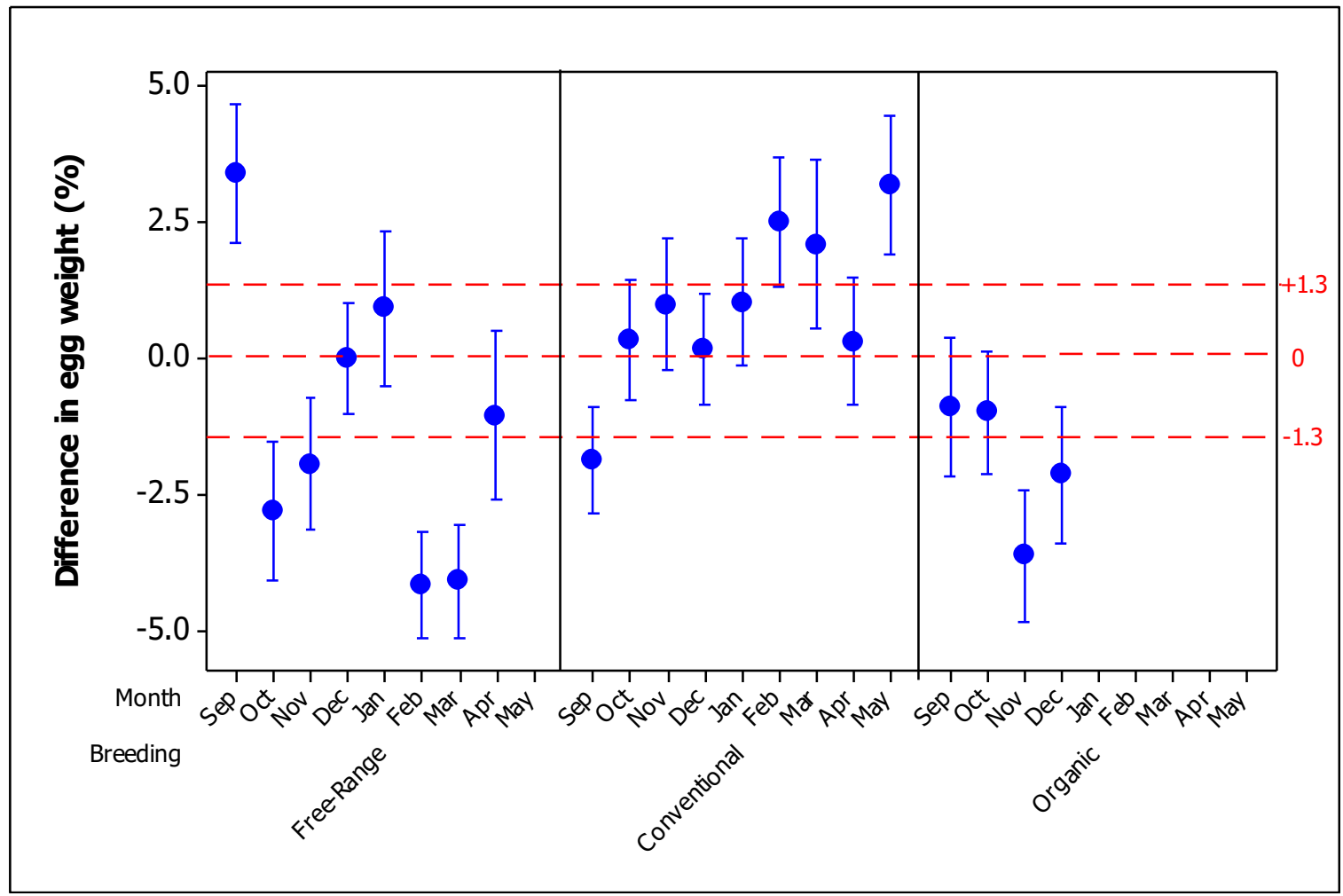

FIGURE 1. Average points and observed normalized variations of the variable egg weight for the three production systems analyzed, compared to the expected values for the lineage, considering the age of each lot in each recorded observation.

The reference value for egg weight (indicated range in the graph on Figure 1) is described in the lineage manual (Hy-Line do Brasil, 2015) and varies according to the age of the birds. We observed that the eggs of the conventional system are better positioned in the range expected for the egg weight (Figure 1), showing an average difference of $0.97 \% \pm 4.78 \%$ above the average expected by the lineage manual. On the other hand, the eggs of the free range and organic system presented greater weight variation $(-1.20 \% \pm 5.33 \%$ and $-1.91 \% \pm 4.81 \%$, respectively), even though they were below the expected weight range in some months. These results corroborate with Jones et al. (2014), who found that eggs from free range systems had significantly lower weights than eggs from birds raised in enriched cages. Steenfeldt \& Hammershoj (2015), in experiments with laying hens in the organic system, verified that the lineage and age of the birds have a greater influence on egg weight than nutrition.
Thus, the results probably indicate that observed changes in egg weight among production systems are more strongly associated with the use of cages in production than bird nutrition.

Over time the egg weight of the conventional system had a tendency to increase, in a greater proportion than expected. Barbosa et al. (2012) point out that egg weight increases with the age of the birds. However, eggs from alternative systems did not show this trend. According to the producer, these results are due to pathologies affected in the free range plot in September 2015 and January 2016. Considering this information, it can be associated with these results that the birds of alternative systems were more exposed to diseases, affecting the quality of the eggs.

The peel strength observed for the three systems is shown in Figure 2, where the dotted center line indicates the expected value of the peel strength. 


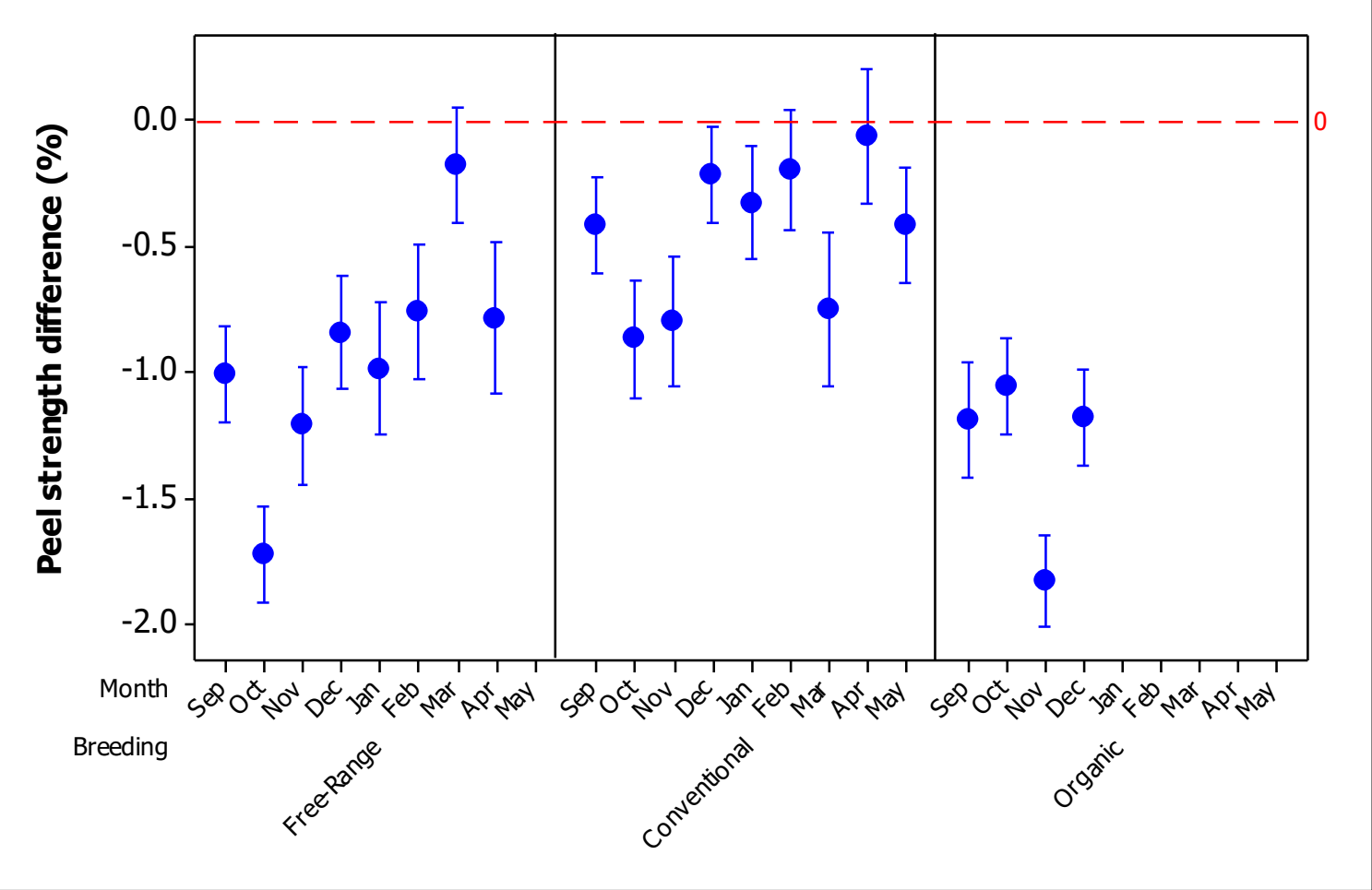

FIGURE 2. Average points and normalized variations observed for the variable of the peel strength for the three evaluated production systems, compared to the expected value for the lineage, considering the age of each lot in each recorded observation.

The three systems presented average peel strength always lower than expected. The reference value of peel strength used (zero value in the graph of Figure 2) was obtained in the lineage manual (Hy-Line do Brasil, 2015) and ranged from 4.35 to $3.98 \mathrm{kgf}$, according to the age of 47 to 82 weeks. However, in the conventional system the peel strength varied less and presented values closer to the reference of the lineage, being in average $0.45 \% \pm 0.96 \%$ smaller. The free range and the conventional systems the mean peel strength were respectively $0.94 \% \pm 1.01 \%$ and $1.31 \% \pm 0.82 \%$ lower than the reference for the lineage.

According to information from the producer, the emergence of a pathology (not identified) in September in the alternative systems also interfered in the results of the peel strength. Jones et al. (2014) found that peel strength was significantly higher for eggs with enriched cages compared to the free range system. Golden et al. (2012) indicate that cage confinement may be associated with the consumption of a more balanced diet capable of partitioning a higher percentage of the nutrient indicated for the eggs production.

In addition to financial losses with losses due to egg breaks with low peel strength, there is also a concern for food safety. The main function of the peel is to protect the contents of the eggs and the eggs produced in the alternative systems, because they have less peel strength and are placed in nests or on marvalha bed and in contact with waste, they are more subject to microbiological contamination.

The Haugh unit index was analyzed for the three systems (Figure 3). The center dashed line indicates the expected value for this variable. 


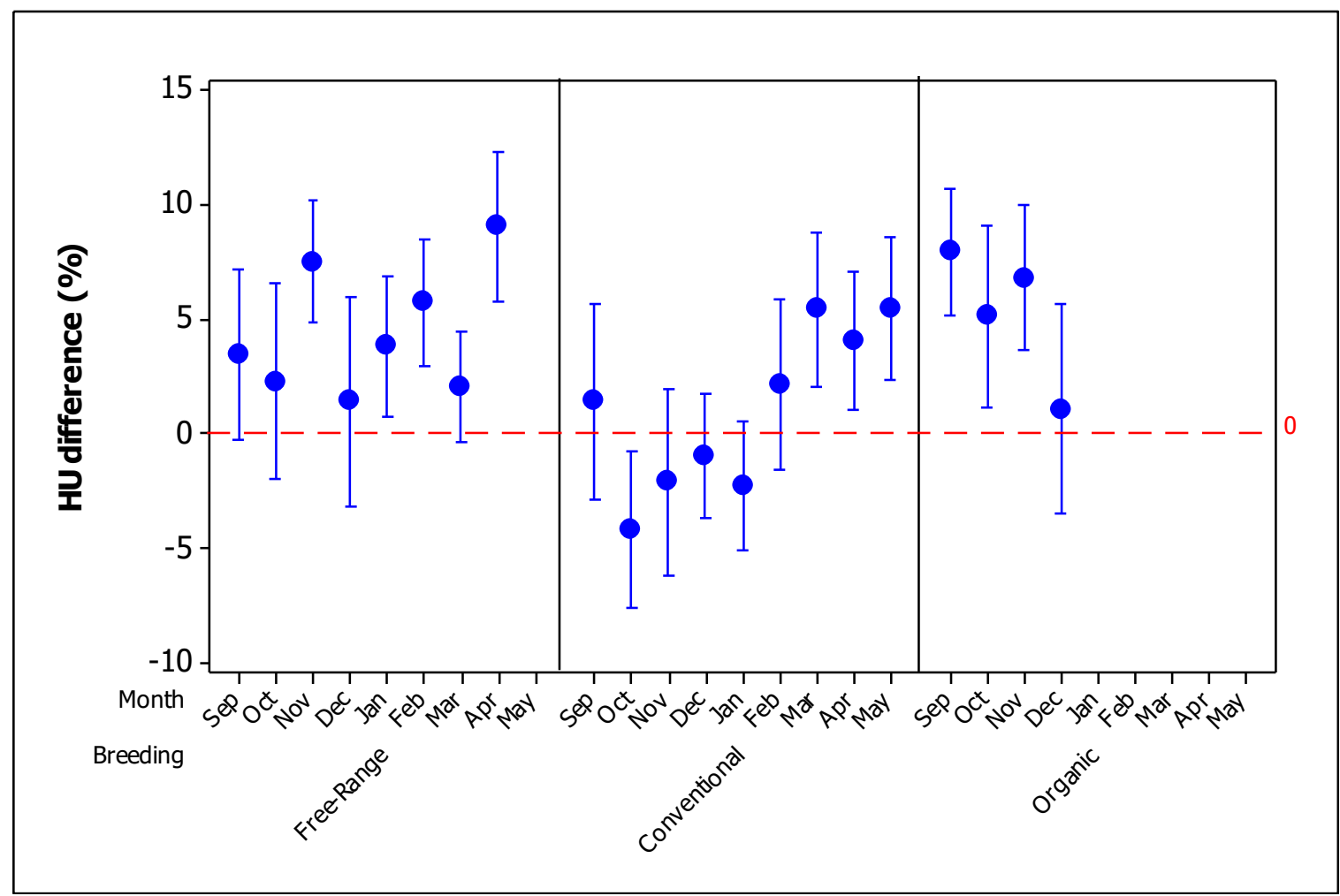

FIGURE 3. Average points and normalized variations observed for the Haugh unit variable for the three systems evaluated, compared to the expected value for the lineage, considering the age of each lot in each recorded observation.

All systems had mean Haugh units higher than expected (Free range: $4.38 \% \pm 13.31 \%$, Organic: $5.25 \% \pm$ 14.31\%, Conventional: $1.06 \% \pm 13.41 \%$ ). According to Hy Line do Brasil (2015) the value of HU varies between 86.5 and 79.7 for the ages of 47 to 82 weeks. Figueiredo et al. (2011) and Oliveira (2014) report that the Haugh unit indicates the presence of water and carbon dioxide in the albumin which renders it more fluid and with altered taste. Higher Haugh unit rates point to better egg quality.

The eggs of the free range and organic systems were in all collections with data above that expected for the Haugh unit, while the conventional system presented below-expected records in the months of September to December, i.e. in the months of high temperatures in the region. The nutritional factor is directly linked to the quality and production of eggs and Steenfeldt \& Hammersoj (2015) indicate that birds of systems without cages can have their nutrition affected, result of insects or vegetation that can come to be ingested by the birds.
High temperatures and heat waves are often associated with productive losses in animals (Vale et al., 2008; Nascimento et al., 2014; Sartori, 2009). According to Campos (2000), in tropical climates, birds, even housed in indoor environments, are subject to thermal loads of radiation greater than their metabolic heat production. Thus, confined birds are likely to exhibit greater heat stress under hot-air conditions. Golden et al. (2012) and Jones et al. (2014) found higher values of Haugh unit in caged birds when compared to eggs of free-range system, contradicting what was observed in this research.

Mortality was also observed and the results are shown in Figure 4. For this variable, the total number of dead birds was considered in the period between the data records, that is, 30-day period, in each breeding system, with the expected lineage for each age corresponding to the lot at the time of collection. 


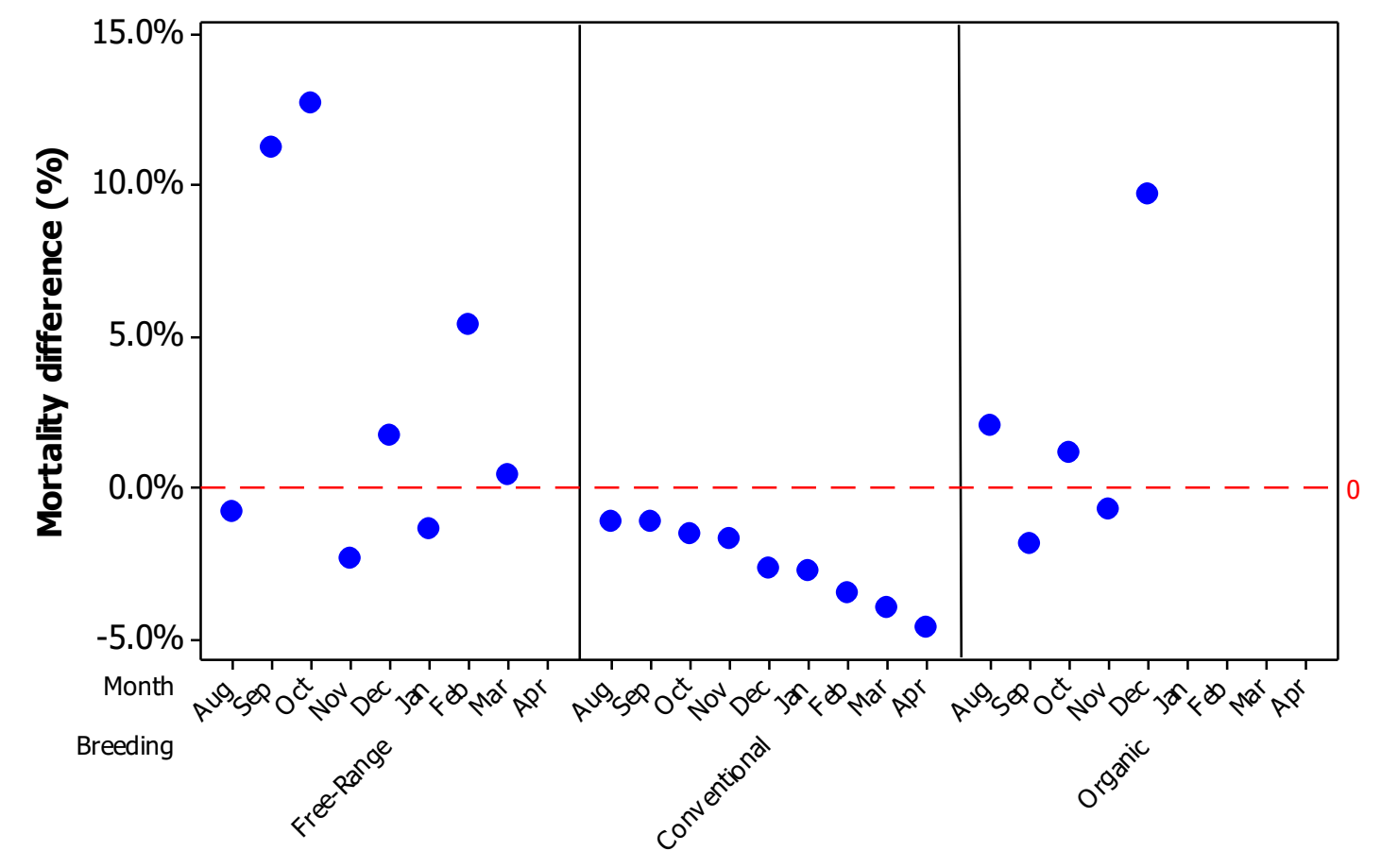

FIGURE 4. Total mortality of birds during the 30 day period, in the three systems evaluated, compared to the expected value for the lineage and considering the age of each lot in each recorded observation.

The cumulative mortality for lots of the Hy Line Brown range varies from $1.9 \%$ to $5.4 \%$, respectively, for the 47 and 82 week ages (Hy-Line do Brasil, 2015), which were the ages of birds evaluated in this study. The conventional system had lower than expected mortality ($2.5 \% \pm 0.01 \%)$, and had little variation between the monthly records. Golden et al. (2012) found that cage birds had a lower mortality rate when compared to birds raised in the free-range system, corroborating with the results of this research.
The free range and organic systems had higher mortality rates $(3.4 \% \pm 0.05 \%$ and $2.1 \% \pm 0.04 \%$, respectively), influenced mainly by the pathology that affected the birds in these systems. According to Azevedo et al. (2016), the control of diseases that can lead to death in birds is even more difficult in alternative systems, given the restriction in the use of antibiotics and other drugs. The dispersion of mean points of mortality in other periods and in the organic system indicates that the best mortality control is in the conventional system.

The productivity of each production system was recorded and analyzed also in periods of 30 days (Figure 5). 


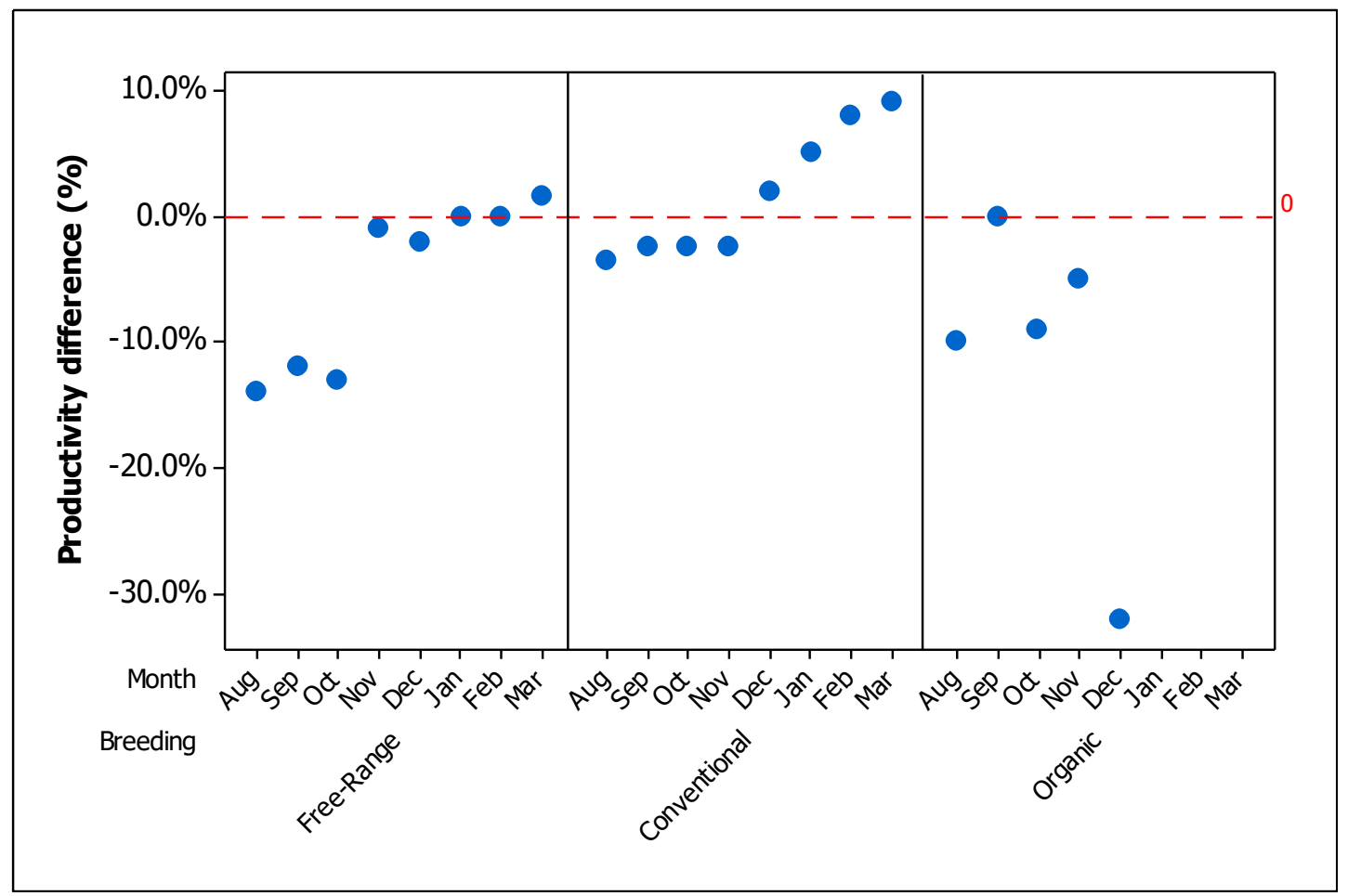

FIGURE 5. Número total de ovos colocados em cada um dos três sistemas de produção avaliados, normalizados e comparados com os valores esperados para a linhagem, considerando a idade de cada lote em cada observação registrada.

The three systems at some moments presented production values lower than expected for the age of the birds, and in the alternative systems they were much lower. These results arise from responses to variations in the thermal environment, in the feeding of birds and occurrences of pathologies. Lemos et al. (2016) points out that achieving high productivity is almost impossible without nutritional control and the use of food additives, which explains the better results of confined birds, even though they have found better welfare conditions in reared poultry in alternative systems. Alves (2006) stated that birds raised under maravalha bedding in systems with better comfort index did not show differences in productivity when compared to cage birds, indicating that if alternative systems are well managed, they can provide similar results to the conventional system. Thus, as the alternative systems in this research had problems with disease control, including the early disposal of lots, the lower results of these systems can result from management failures.

\section{CONCLUSIONS}

The production, the egg external quality and mortality were better in the conventional cage system.

Already the internal quality of eggs was better in alternative systems. The alternative systems had greater variability in results and problems with disease control, which indicate greater difficulty for proper management.

\section{ACKNOWLEDGEMENTS}

We would like to thank to FAPESP Process N. 2015 / 21204-9 for the scholarship awarded, to the Bastos Biological Institute for the support in the analysis of the eggs and the producers who made their farms available for research.

\section{REFERENCES}

Alleoni ACC, Antunes AJ (2001) Unidade Haugh como medida da qualidade de ovos de galinha armazenados sob refrigeração. Scientia Agrícola 58(4): 681-685

Alves SP (2006) Uso da zootecnia de precisão na avaliação do bem-estar bioclimático de aves poedeiras em diferentes sistemas de criação. Doutorado, Universidade de São Paulo, Escola Superior de Agricultura "Luiz de Queiroz".

Azevedo GS, Souza JPL, Cardoso JA, Araújo PHH, Santos Neta ER, Novas MPV (2016) Produção de aves em sistema orgânico. Publicações em Medicina Veterinária e Zootecnia 10(4):327-333.

Barbosa VM, Baião NC, Mendes PM, Rocha JS, Pompeu MA, Lara LJ, Cardoso DM (2012) Avaliação da qualidade da casca dos ovos provenientes de matrizes pesadas com diferentes idades. Arquivo brasileiro de medicina veterinária e zootecnia 64(4):1036-1044.

Campos EJ (2000) Avicultura: Razões, fatos e divergências. Belo Horizonte, FEP-MVZ. 311p.

Figueiredo TC, Cançado SV, Viegas RP, Rêgo IO, Lara LJ, Souza MR, Baião NC (2011) Qualidade de ovos comerciais submetidos a diferentes condições de armazenamento. Arquivo brasileiro de medicina veterinária e zootecnia 63(3):712-720.

Golden JB, Arbona DV, Anderson KEA (2012) Comparative examination of rearing parameters and layer production performance for brown egg-type pullets grown for either free-range or cage production. The Journal of Applied Poultry Research 21(1):95-102

Hy-Line do Brasil (2015) Manual de manejo Hy-Line Brown. 38p. 
Jones DR, Anderson KE, Guard JY (2012) Prevalence of coliforms, salmonella, listeria, and campylobacter associated with eggs and the environment of conventional cage and free-range egg production. Poultry science 91(5):1195-1202.

Jones DR, Karcher DM, Abdo Z (2014) Effect of a commercial housing system on egg quality during extended storage. Poultry science 93(5):1282-1288.

Lemos MJ, Calixto LFL, Torres-Cordido KAA, Reis TL (2016) Uso de aditivo alimentar equilibrador da flora intestinal em aves de corte e de postura. Arquivos do Instituto Biológico 83:1-7.

Moura DJ, Nääs IA, Pereira DF, Silva RBTR, Camargo GA (2006) Animal welfare concepts and strategy for poultry production: a review. Revista Brasileira de Ciência Avícola 8(3):137-147.

Nascimento CCN, Nascimento MRBM, Silva NAM (2014) Occurrence of heat waves in Triangulo Mineiro and Alto Paranaíba and their effect on milk yield and feed intake in cattle. Bioscience Journal 30(5):1488-1495
Oliveira DL, Nascimento JW, Camerini NL, Silva RC, Furtado DA, Araujo TG (2014) Desempenho e qualidade de ovos de galinhas poedeiras criadas em gaiolas enriquecidas e ambiente controlado. Revista Brasileira de Engenharia Agrícola e Ambiental 18(11):1186-1191.

Sartori EV (2009) Concentração de proteínas em gemas de ovos de poedeiras (Gallus gallus) nos diferentes ciclos de postura e sua interferência na disponibilidade do ferro. Ciência e Tecnologia de Alimentos 29(3):481-487.

Steenfeldt S, Hammershøj M (2015) Organic egg production. I: Effects of different dietary protein contents and forage material on organic egg production, nitrogen and mineral retention and total tract digestibility of nutrients of two hen genotypes. Animal Feed Science and Technology 209:186-201.

Tonsor GT, Wolf CA (2011) On mandatory labeling of animal welfare attributes. Food Policy 36(3):430-437.

Vale MM, Moura DJ, Nääs IA, Oliveira SRM, Rodrigues LHA (2008) Caracterização e previsão de ondas de calor com impacto na mortalidade de frangos de corte. Scientia Agricola 65(3):223-229. 